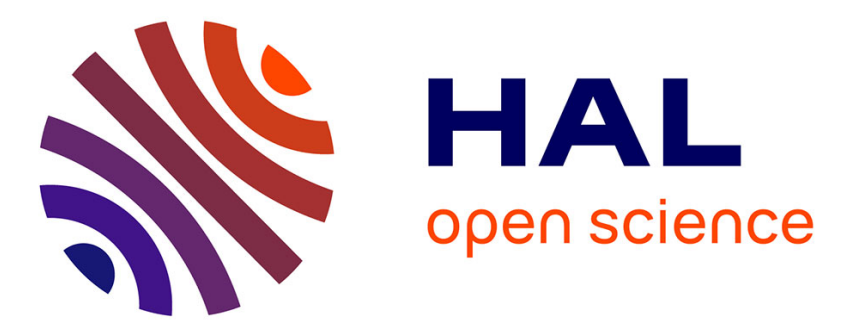

\title{
Predators of the tick Amblyomma variegatum (Acari: Ixodidae) in Guadeloupe, French West Indies
}

\author{
Nicolas Barré, Hervé Mauléon, Glen Garris, Alain Kermarrec
}

\section{To cite this version:}

Nicolas Barré, Hervé Mauléon, Glen Garris, Alain Kermarrec. Predators of the tick Amblyomma variegatum (Acari: Ixodidae) in Guadeloupe, French West Indies. Experimental and Applied Acarology, 1991, 12, pp.163-170. 10.1007/BF01193464 . hal-02714935

\section{HAL Id: hal-02714935 \\ https://hal.inrae.fr/hal-02714935}

Submitted on 1 Jun 2020

HAL is a multi-disciplinary open access archive for the deposit and dissemination of scientific research documents, whether they are published or not. The documents may come from teaching and research institutions in France or abroad, or from public or private research centers.
L'archive ouverte pluridisciplinaire HAL, est destinée au dépôt et à la diffusion de documents scientifiques de niveau recherche, publiés ou non, émanant des établissements d'enseignement et de recherche français ou étrangers, des laboratoires publics ou privés.

\section{다(1)(2)}

Distributed under a Creative Commons Attribution - ShareAlikel 4.0 International 


\title{
Predators of the tick Amblyomma variegatum (Acari: Ixodidae) in Guadeloupe, French West Indies
}

\author{
N. Barré*, H. Mauléon**, G.I. Garris*** and A. Kennarrec**
}

*Institut d'Elevage et de Médecine Vétérinaire des Pays Tropicaux, CIRAD, B.P. 1232, 97184 Pointe-a-Pitre
Cedex, Guadeloupe
**Institut National de la Recherche Agronomique, CRAAG, B.P. 1232, 97184 Pointe-a-Pitre Cedex,
Guadeloupe
***USDA, ARS, Southern Plains Area, Knipling-Bushland U.S. Livestock Insects Research Laboratory, P.O.
Box 232, Kervi/le, Texas, USA
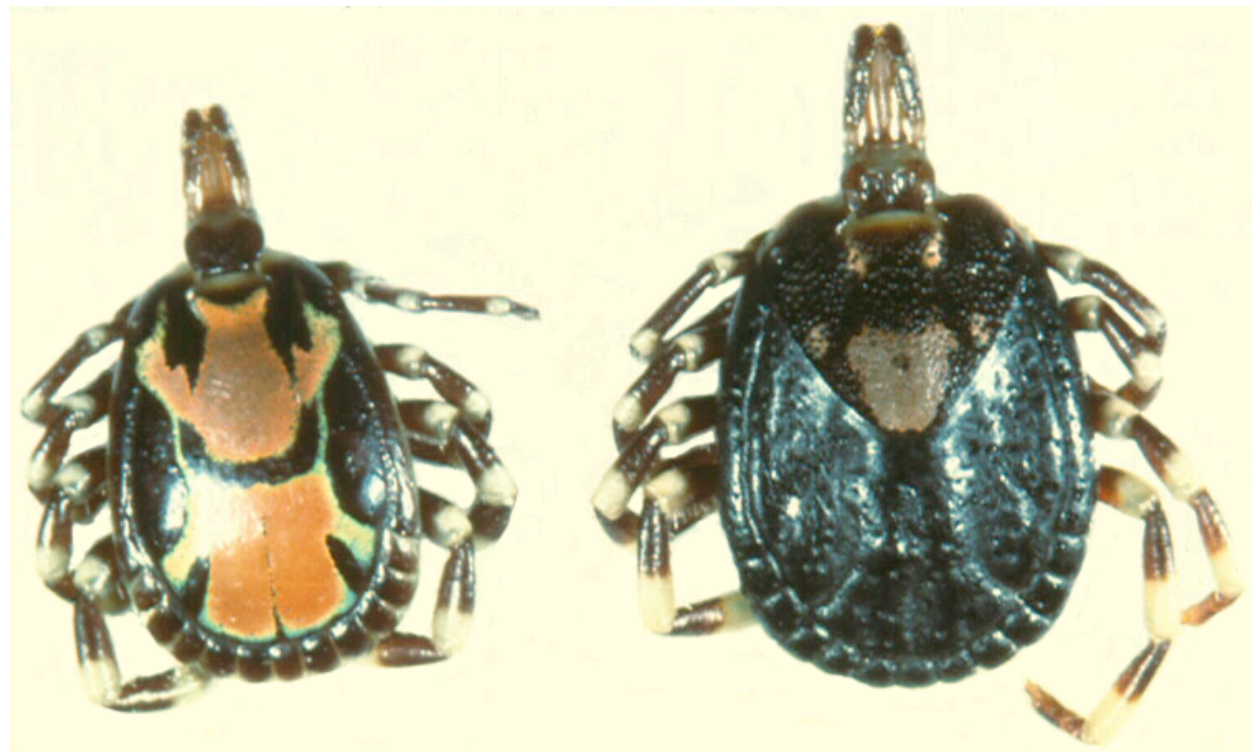

\section{ABSTRACT}

Some vertebrate species in Guadeloupe are predators of free or parasitic stages of Amblyomma variegatum (Fabricius). Among birds, 1.9\% of the 421 identitied animais found in the stomachs of grackles (Quiscalus lugubris), 1.6\% ofthe 364 animais found in the stomachs offree-ranging chickens, and $0.3 \%$ of the 4642 animais found in the stomach of cattle egrets (Bubulcus ibis) were A. variegatum ticks. The most efficient predator of ticks was the tropical tire ant, Solenopsis geminata, which was observed to only attack engorged stages of ticks. An average of $8 \%$ of the 564 individual ticks or batch ofticks released on the ground, mainly in a grass environment, were attacked by this ant species. Mice (Mus musculus) and mongooses (Herpestes auropunctatus) feed on engorged nymphs and female ticks. None of the 15 strains of entomophagous nematodes, genera Steinernema and Heterorhabditis, experimentally put in contact with engorged larvae and nymphs were able to parasitize them. In the laboratory, the insects Megaselia scalaris (Diptera) and Tineola sp. (Lepidoptera) were occasionally found to feed on engorged and unfed ticks, respectively. 


\section{INTRODUCTION}

Amblyomma variegatum (Fabricius) causes significant economic losses to cattle fanners and small ruminant livestock industries in the Caribbean by its direct pathological effect and from transmission of diseases. Amblyomma variegatum transmits Cowdria ruminantium, the causative agent ofheartwater, and is associated with dermatophilosis, a severe skin disease caused by Dermatophilus congolensis (Uilenberg et al., 1984). This tick species, introduced from Africa into the Caribbean in the 19th Century, is found extensively throughout Guadeloupe, and represents a threat to livestock in North, Central, and South America (Sutherst and Maywald, 1985; Barré et al., 1987). Application of an acaricide as sprays for treatment of Iivestock is the principal method oftick control. However, other methods oftick control such as controlled burning, pasture spelling, and biologica1 control could be used in combination with acaricides (Barré, 1988). ln general, there is a lack of information documenting the factors causing natural mortality in tick populations and especially mortality due to parasites and predators. Additional information in this area might lead to more efficient tick-control methods. We present in this article observations made in Guadeloupe over several years on some natural parasites and predators of A. variegatum.

\section{MATERIALS AND METHODS}

\section{Birds}

Bird predators of $A$. variegatum were identified by collection and examination of their stomach contents. The stomach contents of eight free-ranging chickens, 11 cattle egrets, and 62 Caribbean grackles were examined. Arthropods and animaIs found in the stomachs were identified to class or order. Ticks found in the stomachs were identified to species and stage. In addition, regurgitated pellets from cattle egrets at roosts were collected from the ground on five dates in 1983 and 1984. These pellets were isolated and the contents identified.

Ants

A total of 564 observations were made on the effect of ants on the survival of engorged A. variegatum of different stages over several years and in different environments. Engorged female ticks were released separately and their position in the grass marked with plastic stakes. Engorged larvae and nymphs were released in plastic containers covered with a 1.8$\mathrm{mm}$-mesh plastic cloth. The large-sized mesh cloth selectively allowed for the entrance of ants and prevented entrance of larger arthropods. AlI engorged ticks were examined one to seven days after release and the number damaged recorded. Samples of ants present in the vials or feeding on engorged female ticks at one to three days after release were collected and identified to species.

\section{Rodents}

We attempted to identify predation of ticks by rodents on the basis of teethmarks on plastic vials containing ticks released in field survival studies. Teeth imprints were matched with rodent species' feeding habits and abundance.

\section{Nematodes}

Fifteen different strains of entomophagous nematodes, collected from soil sam pies from different areas of Guadeloupe, as weIl as known strains of entomopathogenic nematodes were used in laboratory studies to determine the infectivity ofthese organisms for fed or unfed ticks. Two strains and one strain of Heterorhabditis nematodes were collected from soils in Guadeloupe and Canada, respectively, and cultured to obtain pure strains for use in these studies. Other nematodes used included $H$. bacteriophora, H. heliothidis, Steinernema anomali, S. bibionis, S. carpocapsae, and S. glaseri. AIl strains of nematodes studied were used in attempts to infect all engorged stages and instars of $A$. variegatum, and four strains were also injected in attempts to infect selected engorged A. variegatum ticks. Experiments were conducted in Petri dishes covered with filter paper impregnated with $0.1 \mathrm{ml}$ of a solution containing 1000 infective larval nematodes. In each experiment, five ticks were placed in each 
of three Petri dishes which contained the infective stages of different strains of nematodes tested. After ticks were introduced, Petri dishes were maintained at $25^{\circ} \mathrm{C}$ in darkness. Abbott's (1925) formula was used to calculate the mortality of ticks each day. Dead ticks were dissected three days after death in order to verify the penetration and development of the nematodes.

\section{Miscellaneous predators}

A colony of ticks has been maintained in the laboratory in Guadeloupe since 1982. During this period of time, a Diptera and a Lepidoptera species has been observed attacking ticks..

\section{RESULTS AND DISCUSSION}

\section{Birds}

Active predation of ticks by birds while attached to a host such as cattle was rarely observed on Guadeloupe. However, both the cattle egret and the Caribbean grackle were observed to pull ticks of hosts. Grackles were more often seen perched on the backs of cattle or goats, apparently there to feed on the attached ticks, than were cattle egrets. Results from the examination of stomach contents from adults of three common birds in Guadeloupe, the cattle egret, Caribbean grackle, and freeranging chickens, ar presented in Tables 1 and 2. A total of 5427 different animais or arthropod were identified in the stomach contents. The main diet of cattle egrets was Orthoptera (33.5\%), Diptera (25.6\%), Lepidoptera (11.6\%), and Anolis lizards (7.8\%). Cattle egrets were found to consume large amounts of Diptera larvae, especially those species found around garbage-disposal sites. Lizards were more common in the regurgitated pellets collected from young birds at nesting sites. Coleoptera (33.7\%) and Lepidoptera (36.1\%) were the main arthropods found in the stomachs of Caribbean grackles. The predominant species of arthropods found in the stomach contents of free-ranging chickens were Coleoptera (42\%) and Hymenoptera (ants; 24\%).

Table 1. Animals found in the stomachs or regurgitated pellets of cattle egrets and the stomachs of Caribbean grackles and free-ranging chickens examined in Guadeloupe

\begin{tabular}{|c|c|c|c|c|c|}
\hline \multirow[t]{2}{*}{ Animal } & \multicolumn{2}{|c|}{ Cattle egret } & \multirow{2}{*}{$\begin{array}{c}\text { Caribbean grackle } \\
\begin{array}{c}\text { Stomach } \\
(\mathrm{n}=62)\end{array}\end{array}$} & \multirow{2}{*}{$\begin{array}{c}\text { Chicken } \\
\begin{array}{c}\text { Stomach } \\
(\mathrm{n}=8)\end{array}\end{array}$} & \multirow[t]{2}{*}{ Total } \\
\hline & $\begin{array}{l}\text { Pellets } \\
(\mathrm{n}>50)\end{array}$ & $\begin{array}{c}\text { Stomach } \\
(\mathrm{n}=11)\end{array}$ & & & \\
\hline $\begin{array}{l}\text { Annelida } \\
\text { C. Oligochaeta }\end{array}$ & 13 & 1 & 0 & 0 & 14 \\
\hline $\begin{array}{l}\text { Mollusca } \\
\text { C. Gastropoda }\end{array}$ & 1 & 0 & 3 & 18 & 22 \\
\hline $\begin{array}{l}\text { Arthropoda } \\
\text { C. Acachnida }\end{array}$ & & & & & \\
\hline O. Araneida & 182 & 71 & 17 & 0 & 270 \\
\hline O. Ixodida & 86 & 2 & 9 & 6 & 103 \\
\hline C. Crustacea & 11 & 0 & 1 & 0 & 12 \\
\hline $\begin{array}{l}\text { C. Myriapoda } \\
\text { C. Insecta }\end{array}$ & 48 & 13 & 0 & 12 & 73 \\
\hline O. Odonata & 6 & 9 & 0 & 0 & 15 \\
\hline O. Dictyoptera & 24 & 15 & 0 & 7 & 46 \\
\hline O. Orthoptera & 1270 & 287 & 33 & 3 & 1593 \\
\hline O. Dermaptera & 1 & 4 & 0 & 58 & 63 \\
\hline O. Coleoptera & 167 & 14 & 152 & 153 & 486 \\
\hline O. Lepidoptera & 274 & 267 & 137 & 17 & 695 \\
\hline O. Diptera & 768 & 420 & 33 & 3 & 1224 \\
\hline O. Hymenoptera & 50 & 43 & 27 & 87 & 207 \\
\hline O. Heteroptera & 3 & 6 & 6 & 0 & 15 \\
\hline
\end{tabular}




\begin{tabular}{|l|c|c|c|c|c|}
\hline Vertebrata & 24 & 0 & 0 & 0 & 0 \\
C. Fish & 176 & 7 & 0 & 0 & 183 \\
C. Amphibia & 360 & 6 & 3 & 0 & 369 \\
C. Reptilia & 10 & 3 & 0 & 364 & 5427 \\
C. Mammalia & 3474 & 1168 & 421 & & \\
Total & & & & & 0 \\
\hline
\end{tabular}

C, Class; O, Order

ln Guadeloupe, cattle egrets, Caribbean grackles, and chickens seem to play a significant role as predators of insects (Table 1). These birds also act as hosts for ticks, and may be involved in the spread of A. variegatum in the Caribbean (Alderink and McCauley, 1988; Barré et al., 1988; Barré and Garris, 1990). Their role as predators of A. variegatum is limited (Table 2). Of the total animais found in the stomach contents or in the regurgitated pellets collected at the nesting sites, only 103 of them were ticks, and of these, $70 \%$ were engorged females of $B$. microplus. A plausible explanation fo $\mathrm{r}$ the large proportion of $B$. microplus ticks found in the stomach contents examined in this study might be that Boophilus ticks have short mouth-parts which do not penetrate into the dermallayer of the skin, whereas Amblyomma ticks have long mouth-parts which do penetrate deep into the dermallayer of the skin, thus making removal by cattle egrets more difficult. In addition, Amblyomma ticks are mainly found attached to the axillary and udder regions of the animal, areas which are more difficult to reach and which would not be accessible to cattle egrets walking and feeding near cattle.

Table 2. Total numbers and stage ofticks found in stomach contents or regurgitated pellets from cattle egrets, Caribbean grackles and free-ranging chickens examined in Guadeloupe

\begin{tabular}{|c|c|c|c|c|c|}
\hline \multirow[t]{2}{*}{ Tick/intar } & \multicolumn{2}{|c|}{ Cattle egret } & \multirow{2}{*}{$\begin{array}{c}\text { Caribbean grackle } \\
\begin{array}{c}\text { Stomach } \\
(\mathrm{n}=62)\end{array} \\
\end{array}$} & \multirow{2}{*}{$\begin{array}{c}\text { Chicken } \\
\begin{array}{c}\text { Stomach } \\
(\mathrm{n}=8)\end{array}\end{array}$} & \multirow[t]{2}{*}{ Total } \\
\hline & $\begin{array}{l}\text { Pellets } \\
(\mathrm{n}>50)\end{array}$ & $\begin{array}{c}\text { Stomach } \\
(\mathrm{n}=11)\end{array}$ & & & \\
\hline B. microplus & & & & & \\
\hline Female (Fed) & 71 & 0 & 1 & 0 & 72 \\
\hline A. variegatum & & & & & \\
\hline Larva (Fed) & 0 & 0 & 0 & 1 & 1 \\
\hline Nymph & 1 & 0 & 0 & 2 & 3 \\
\hline Nymph (Fed) & 5 & 0 & 0 & 3 & 8 \\
\hline Female & 0 & 0 & 4 & 0 & 4 \\
\hline Female (Fed) & 9 & 2 & 1 & 0 & 12 \\
\hline Male & 0 & 0 & 3 & 0 & 3 \\
\hline
\end{tabular}

About 2\% of the stomach contents of cattle egrets examined in this survey contained ticks. McKilligan (1984) found 4.5\% of the stomach contents of cattle egrets examined in Australia to contain Boophilus ticks. In other studies, by Siegfried (1971) and Telfair and Marcy (1984), few ticks were recovered from the stomachs of cattle egrets. Considering the number of cattle egrets in Guadeloupe and the number of animaIs collected each day as food by cattle egrets (Siegfried, 1971 ), we speculate that about 1 Amblyomma per cow per day is consumed by this bird. This suggests that cattle egrets do not play a significant role in regulating Amblyomma tick populations in Guadeloupe. Predation by these birds on ticks appears to be an opportunistic event, and is probably related to the level of infestation of ticks on cattle near where these birds are feeding.

Free-ranging chickens may play an important role as predators of ticks (Newstead, 1910; Bequaert, 1930). These domestic birds are usually associated with cattle and other domestic livestock around farms, and are important protein sources in a traditional farming system in the tropics. In this study, both unfed and engorged ticks were found in the stomachs of these birds. Morel (1974) observed chickens picking ticks from resting cattle in Africa, and suggested that these birds could easity be used as an additional tick-control method in a 
traditional livestock production system in the tropics. However in the chickens studied in Guadeloupe, only $1.6 \%$ oftheir total diet was ticks. Therefore, our data for Guadeloupe suggest that chickens would have !ittle effect on tick populations.

Ants

In ail cases, the tropical fire ant, Solenopsis geminata, was the only ant found feeding on ticks. In field experiments where ticks were released, no ants were observed to feed on unfed and mobile ticks, but $17.5 \%, 7.1 \%$ and $14.6 \%$ of engorged larvae, nymphs, and females, respectively, were attacked by this ant (Table 3 ).

The attack sequence for all ticks by the Solenopsis ant was the same, simitar to that described by Colon-Guasp (1985). After locating a tick, the ants cut off its legs, opening an entrance into the inside at or near the coxae. Next, they then penetrate the tick and begin removing the internaI contents. This material is returned to the mound. While one group of ants is disassemb!ing the tick, a second group is burying it by removing soit from underneath. Ticks were observed to be attacked by this ant as quicldy as within a few hours after release, or as long as up to seven days.

Solenopsis geminata are known predators ofticks and have been observed to cause a significant level of mortality in populations of engorged Boophilus ticks (Weber, 1948; Butler et al., 1979; Colon-Guasp, 1985). The results presented in this paper report, for the first time, predation by this ant on A. variegalum. In our studies, this ant was observed to attack up to $35 \%$ of released and engorged larvae in grass environments in Duclos. However, the total rate of predation for all engorged ticks released (only 9.2\% were attacked) would suggest that predation by this ant on A. variegalum in Guadeloupe would have little effect on populations. Nevertheless, this ant is the most important predator in Guadeloupe, and may have a local or seasonal effect of reducing tick populations in grass environments. Additional research is needed to determine the importance of this predator in regulating tick populations.

Table 3. Number of A. variegatum released on Ihe ground in grass environmenls al Gardel and Duclos in Guadeloupe. and Ihe number allacked by So/erwpsis geminata

\begin{tabular}{|c|c|c|c|c|}
\hline \multirow{2}{*}{ Instar released } & \multicolumn{2}{|c|}{ Gardel } & \multicolumn{2}{|c|}{ Duclos } \\
\cline { 2 - 5 } & $\begin{array}{c}\text { Released } \\
(\mathrm{n})\end{array}$ & $\begin{array}{c}\text { Attacked } \\
(\mathrm{n},(\%))\end{array}$ & $\begin{array}{c}\text { Released } \\
(\mathrm{n})\end{array}$ & $\begin{array}{c}\text { Attacked } \\
(\mathrm{n},(\%))\end{array}$ \\
\hline Larva (Fed) & 20 & $0(0)$ & 20 & $7(35)$ \\
Nymph (Fed) & 148 & $7(5)$ & 244 & $0(0)$ \\
Adults & 26 & $0(0)$ & 29 & $6(17)$ \\
Female (Fed) & 41 & $6(15)$ & 36 & $(9)$ \\
\hline
\end{tabular}

\section{Rodents}

From the examination of teeth marks, mice (Mus musculus) and mongooses (Herpestes auropunctatus) were found to tear open specially constructed plastic vials partially covered with cloth, to consume engorged nymphal and female $A$. variegatum. The vials and ticks were released in field plots to determine longevity and survival. Over a two-and-a-half-year period, less than $1 \%$ of the 1300 vials of ticks released were attacked by these mammals.

\section{Nematodes}

No significant mortalities were observed seven days after contact between the nematodes and various instars of the tick at different stages of engorgement. Nematodes were not infective, even when injected into ticks. Nematodes have no effect on tick populations in Guadeloupe.

\section{Miscellaneous predators .}

ln colony ticks, Megaselia scalaris (Diptera) and Tineola sp. (Lepidoptera) were found attacking ticks. Megaselia scalaris were observed to attack about $5 \%$ of vials which contained large numbers of engorged nymphal ticks. We observed that this fly was infecting only those vials which contained dead ticks. Infestations by this fly in the colony has been eliminated by reducing the number of ticks maintained in each vial and by keeping vials clean of dead ticks. 
Megaselia scalaris has been observed feeding on engorged ticks in the laboratory in Puerto Rico (Garris, 1983). This fly probably only feeds on dead decaying ticks. It has not been observed feeding on ticks released in field studies. Tineola sp. is a small Lepidoptera that was found infesting about 12 vials of unfed and engorged ticks in the laboratory. In an experiment where five immatures of the moth were placed in a vial with 25 unfed nymphs of $A$. variegatum, the moth immatures were observed to capture 24 of the unfed nymphs in webs of silk and then to eat them.

\section{ACKNOWLEDGMENT}

We wish to thank Professor K. Jaffe of the University of Caracas, Venezuela, for his assistance in the identification of the ant species, and Rosalie Aprelon for her excellent technical assistance.

\section{REFERENCES}

Abbott, W.S., 1925. A method of computing the effectiveness of an insecticide. J. Econ. Entomol., 18: 265-267.

Alderink, F.J. and McCauley, E.H., 1988. The probability of the spread of Amb/yomma variegatum in the Caribbean. Prev. Vet. Med., 6: 285-294.

Barré, N., 1988. Mesures agronomiques permettant une diminution des populations de la tique Amb/yomma variegatum. Rev. Elev. Med. Vet. Pays Trop., 41: 387-393.

Barré, N. and Garris, G.I., 1990. Biology and ecology of Amb/yomma variegatum (Acari: Ixodidae) in the Caribbean. Implications for a regional eradication program. J. Agric. Entomol., 7: 1-9.

Barré, N., Uilenberg, G., Morel, P.c. and Camus, E., 1987. Danger of introducing heartwater onto the American mainland: Potential role of indigenous and exotic Amb/yomma ticks. Onderstepoort J. Veto Res., 54: 405-417.

Barré, N.G., Garris, 1., Borel, G. and Camus, E., 1988. Hosts and population dynamics of Amb/yomma variegatum (Acari: Ixodidae) on Guadeloupe, French West Indies. J. Med. Entomol., 25: 111-115.

Bequaert, J., 1930. Ticks collected by the American museum Congo expedition 1909-1915, with notes on the parasites and predacious enemies ofthese arthropods. Am. Mus. Not., 426: $1-12$.

Butler, J.F., Camino, M.L. and Perrez, T.O., 1979. Boophi/us and the tire ant Solenopsis geminata. Recent Adv. Acarol., 1: 469-472.

Colon-Guasp, W., 1985. Predation of the native tire ant, Solenopsis geminata (Fabricius) (Hymenoptera: Formicidae) on the southem cattle thick, Boophilus microplus (Canestrini) (Acari: Ixodidae) in Puerto Rico. Masters Thesis, U niv. Puerto Rico, 50 pp. (unpublished).

Garris, G.I., 1983. Megaselia scalaris (Diptera: Phoridae) infesting laboratory tick colonies. J. Med. Entomol., 20: 688.

McKilligan, N.G., 1984. The food and feeding ecology of the cattle egret, Ardeola ibis, when nesting in southeast Queensland. Aust. Wildl. Res., Il: 133-144.

Morel, P.C., 1974. Les méthodes de lutte contre les tiques en fonction de leur biologie. Cah. Méd. Vét., 43: 3-23. 
Newstead, R., 1910. Ticks and other blood sucking Arthropoda of J amaica. Bull. Dept. Agric. Jamaica,N.S., 1: 145-175.

Sutherst, R.W. and Maywald, G.F., 1985. A computerised system for matching climates in ecology. Agric. Ecosyst. Environ., 13: 281-299.

Siegfried, W.R., 1971. The food of the cattle egret. J. Appl. Ecol., 8: 447-468.

Telfair, R.C. and Marcy, L.E., 1984. Cattle egrets (Ardeola ibis: Bubulcus ibis) in Texas. Texas J. Sci., 35: 303-314.

Uilenberg, G., Barré, N., Camus, E., Burridge, M.J. and Garris, G.I., 1984. Heartwater in the Caribbean. Prev. Veto Med., 2: 255-267.

Weber, N.A., 1948. Ants from the Leeward group and some other Caribbean localities. Stud. Fauna Curaçao, Aruba, Bonaire Venez. Isl., 14: 78-86. 